\title{
Analisis Efisiensi Penggunaan Input Produksi Usahatani Bawang Merah Pada Masa Pandemi Covid-19 di Kecamatan Peukan Bada Kabupaten Aceh Besar (Efficiency Analysis of Production Input Uses of Shallot Farming During Covid-19 Pandemic in Peukan Bada Sub District of Aceh Besar Regency)
}

\author{
Ninda Fadilla ${ }^{1}$, T. Fauzi ${ }^{1}$, Widyawati ${ }^{1 *}$ \\ ${ }^{1}$ Program Studi Agribisnis, Fakultas Pertanian, Universitas Syiah Kuala \\ *Corresponding author: widyaradja@gmail.com
}

\begin{abstract}
Abstrak. Produksi bawang merah di Peukan Bada mengalami pasang surut setiap tahunnya. Pada masa pandemi Covid-19 ini produksi bawang merah di Peukan Bada mengalami penurunan karena tingginya harga input produksi yang berakibat pada ketidakmampuan petani dalam memenuhi input produksi seperti biasanya. Penelitian ini bertujuan untuk mengetahui pengaruh penggunaan input produksi berupa luas lahan, bibit, pupuk organik, pupuk anorganik, pestisida dan tenaga kerja pada produksi bawang merah pada masa pandemi Covid-19 di Peukan Bada serta untuk mengetahui tingkat efisiensi penggunaan input produksi pada usahatani bawang merah pada masa pandemi Covid-19 di Peukan Bada. Penelitian ini menggunakan metode analisis fungsi produksi Cobb Douglas dan analisis efisiensi harga. Hasil penelitian menunjukkan bahwa diperoleh nilai koefisien determinasi sebesar 0,935 yang menjelaskan bahwa sebanyak $93,5 \%$ produksi usahatani bawang merah dipengaruhi oleh variabel luas lahan, bibit, pupuk organik, pupuk anorganik, pestisida dan tenaga kerja sedangkan 6,5\% sisanya dijelaskan oleh faktor lain diluar penelitian ini. Pada nilai signifikan $0,000<0,05$ yang berarti bahwa penggunaan input produksi yang meliputi luas lahan, bibit, pupuk organik, pupuk anorganik, pestisida dan tenaga kerja secara serempak berpengaruh signifikan terhadap produksi bawang merah di Kecamatan Peukan Bada. Sedangkan secara parsial hanya bibit yang berpengaruh signifikan terhadap produksi bawang merah dengan nilai signifikan $0,007<0,05$ sedangkan untuk luas lahan, pupuk organik, pupuk anorganik, pestisida dan tenaga kerja diketahui nilai sig (pvalue) $>0,05$ sehingga tidak berpengaruh signifikan terhadap produksi bawang merah di Peukan Bada. Pada analisis efisiensi diketahui bahwa nilai NPMx/Px > 1, sehingga penggunaan bibit, pupuk anorganik dan tenaga kerja belum efisien bila diamati dari segi harga sehingga harus ditambah penggunaan input produksinya agar mencapai efisiensi. Kemudian pada variabel luas lahan, pupuk organik dan pestisida diketahui nilai NPMx/Px $<1$ sehingga penggunaan input tersebut tidak efisien bila diamati dari segi harga sehingga harus dikurangi penggunaan input produksinya agar mencapai efisiensi, tercapainya efisiensi akan mengoptimalkan input produksi yang digunakan sehingga hasil produksi menjadi maksimal dan meningkatkan pendapatan petani.
\end{abstract}

Kata kunci : Efisiensi, Input Produksi, Usahatani, Bawang merah, Covid-19, Peukan Bada.

\begin{abstract}
Shallot production in Peukan Bada experiences ups and downs every year. During the Covid-19 pandemic, shallot production in Peukan Bada decreased due to the high price of production inputs which resulted in the inability of farmers to meet production inputs as usual. This study aims to determine the effect of using production inputs in the form of land area, seeds, organic fertilizers, inorganic fertilizers, pesticides and labor on shallot production during the Covid-19 pandemic in Peukan Bada and to determine the level of efficiency in the use of production inputs in shallot farming. during the Covid-19 pandemic in Peukan Bada. This research uses Cobb Douglas production function analysis method and price efficiency analysis. The results showed that the coefficient of determination was 0,935 which explained that $93,5 \%$ of shallot farming production was influenced by the variables of land area, seeds, organic fertilizers, inorganic fertilizers, pesticides and labor, while the remaining $6,5 \%$ was explained by other factors. outside of this research. At a significant value of $0,000<0,05$, which means that the use of production inputs which include land area, seeds, organic fertilizers, inorganic fertilizers, pesticides and labor simultaneously have a significant effect on the production of shallots in Peukan Bada District. While partially only seeds have a significant effect on shallot production with a significant value of $0,007<0,05$ while for land area, organic fertilizers, inorganic fertilizers, pesticides and labor, it is known that the sig (p-value) $>0,05$ so it has no effect. significant effect on shallot production in Peukan Bada. In the efficiency analysis, it is known that the value of NPMx/Px > 1, so that the use of seeds, inorganic fertilizers and labor is not efficient when observed in terms of price so that the use of production inputs must be added to achieve efficiency. Then on the variables of land area, organic fertilizers and pesticides, the value of NPMx/Px $<1$ is known so that the use of these inputs is not efficient when observed in terms of price so that the use of production inputs must be reduced in order to achieve efficiency, achieving efficiency will optimize the production inputs used so that the production results become maximum and increase farmers' income.
\end{abstract}

Keywords: Efficiency, Production Input, Farm, Shallot, Covid-19, Peukan Bada. 


\section{PENDAHULUAN}

Bawang merah dikenal sebagai salah satu sub sektor tanaman pangan yang memenuhi nilai ekonomi konsumsi nasional, sebagai sumber pendapatan petani dan merupakan penyumbang devisa negara yang potensial. Produksi bawang merah di Indonesia biasanya berasal dari bibit bawang merah lokal. Sebagian besar petani umumnya akan langsung menjual bawang merah setelah panen karena membutuhkan penghasilan dan ketidakmampuan petani dalam melakukan penyimpanan dalam skala yang besar dan aman (Nurmala \& Antara, 2015; RAHAYU et al., 2019).

Salah satu sentra produksi bawang merah di Kabupaten Aceh Besar berada di Kecamatan Peukan Bada. Hasil produksi usahatani bawang merah dari Kecamatan Peukan Bada merupakan produksi yang paling tinggi di antara kecamatan lain di Aceh Besar. Dari wawancara langsung dengan Balai Penyuluh Pertanian di Kecamatan Peukan Bada mengatakan bahwa hasil panen bawang merah pada sekali musim tanam di tahun 2019 mencapai $6-8$ ton/ha, sedangkan hasil panen bawang merah pada sekali musim tanam di tahun 2020 hanya berkisar antara $3-4$ ton/ha.

Ketidakstabilan tingkat produksi ini ditentukan oleh penggunaan faktor produksi yang kurang optimal. Perlu juga di waspadai faktor iklim dan cuaca yang dapat membuat turunnya produksi bawang merah. Tingginya curah hujan dan musim kemarau yang panjang serta serangan penyakit merupakan beberapa faktor lain diluar penggunaan input yang mempengaruhi ketidakstabilan hasil panen bawang merah di Kecamatan Peukan Bada. Namun pada kondisi Covid-19 seperti sekarang ini menyebabkan harga input produksi bawang merah meningkat, contohnya harga bibit bawang merah menjadi Rp54.000/kg dari harga $\mathrm{Rp} 25.000 / \mathrm{kg}$, serta harga pupuk organik meningkat dari harga Rp500/kg menjadi Rp700/kg, sedangkan harga pupuk anorganik dan pestisida tidak mengalami kenaikan harga, kemudian pada penggunaan tenaga kerja untuk melakukan kegiatan usahatani bawang merah dikurangi agar menekan pengeluaran petani, hal ini mempengaruhi harga jual bawang merah di pasaran yang ikut meningkat mengikuti harga penggunaan input produksi. Akibatnya produksi bawang merah lokal mengalami penurunan karena tingginya harga input produksi yang berakibat pada ketidakmampuan petani dalam memenuhi input produksi seperti biasanya. Tingginya curah hujan membuat banyak bawang merah yang rusak sehingga tidak dapat menjadi benih, hal ini mengakibatkan tingginya harga bibit bawang merah di beberapa daerah.

Walaupun terdapat keterbatasan sumber daya dalam melaksanakan usahatani, petani bawang merah senantiasa selalu berupaya untuk mencapai keuntungan yang maksimal. Permasalahan yang dialami petani cenderung pada harga input yang meningkat, sedangkan harga output tidak mengikuti kenaikan dari harga input tersebut. Oleh karena itu dibutuhkan efisiensi dalam melaksanakan proses produksi. Agar penggunaan input dapat teralokasi dengan baik maka dibutuhkan kajian serta analisis tertentu. Pada penjabaran diatas maka peneliti tertarik untuk melakukan penelitian tentang bagaimana pengaruh penggunaan input produksi dan tingkat efisiensi pada usahatani bawang merah di Kecamatan Peukan Bada Kabupaten Aceh Besar.

Penelitian ini bertujuan untuk mengetahui pengaruh penggunaan input produksi berupa luas lahan, bibit, pupuk organik, pupuk anorganik, pestisida dan tenaga kerja pada produksi bawang merah pada masa pandemi Covid-19 di di Kecamatan Peukan Bada Kabupaten Aceh Besar serta untuk mengetahui tingkat efisiensi penggunaan input produksi pada usahatani bawang merah pada masa pandemi Covid-19 di Kecamatan Peukan Bada Kabupaten Aceh Besar. 


\section{METODE PENELITIAN}

\section{Tempat dan Waktu Penelitian}

Penelitian ini dilaksanakan pada Kecamatan Peukan Bada yang terletak di Kabupaten Aceh Besar. Lokasi ini dipilih berdasarkan pertimbangan bahwa kecamatan ini merupakan memiliki hasil produksi bawang merah yang paling tinggi di Kabupaten Aceh Besar. Penelitian ini dilakukan dari pada bulan Maret hingga April 2021.

\section{Objek dan Ruang Lingkup Penelitian}

Objek pada penelitian ini yaitu para petani yang memiliki usahatani bawang merah di Kecamatan Peukan Bada selama masa pandemi Covid-19. Ruang lingkup pada penelitian terbatas pada analisis efisiensi penggunaan input produksi pada usahatani bawang merah di Kecamatan Peukan Bada Kabupaten Aceh Besar.

\section{Populasi dan Sampel Penelitian}

Pada penelitian ini populasinya merupakan para petani yang melakukan budidaya bawang merah yang berada di Kecamatan Peukan Bada Kabupaten Aceh Besar selama masa pandemi Covid-19. Kriteria petani sampel adalah petani yang melaksanakan usahatani bawang merah pada masa pandemi Covid-19. Penentuan petani sebagai sampel dilakukan dengan metode total sampling. Menurut (Sugiyono, 2009) total sampling merupakan suatu teknik pengambilan sampel yang jumlah sampelnya sama dengan jumlah populasi. Pemakaian teknik ini dilakukan apabila jumlah populasi ditempat penelitian kurang dari 30 responden. Jumlah populasi pada penelitian ini berjumlah 18 populasi dan seluruhnya merupakan sampel.

\section{Jenis dan Pengumpulan Data}

Penelitian ini menggunakan jenis data yang terdiri dari data primer dan data sekunder. Data primer berasal dari wawancara langsung yang dilakukan dengan petani di daerah penelitian menggunakan kuisioner penelitian. Sedangkan data sekunder didapat dari karya ilmiah terkait, studi kepustakaan, literatur-literatur, dan berbagai instansi yang terkait penelitian ini.

\section{Metode Analisis Data}

Pada penelitian ini menggunakan dua metode analisis yaitu metode analisis fungsi produksi Cobb Douglas dan metode analisis harga.

1. Analisis Fungsi Produksi Cobb Douglas

Analisis fungsi Cobb Douglas merupakan suatu analisis yang melihat suatu hubungan fisik maupun hubungan teknis dalam mengetahui pengaruh input produksi terhadap produksi usahatani bawang merah. Fungsi produksi ini dilakukan untuk mengkaji pengaruh dari input produksi yang digunakan terhadap produksi bawang merah. Secara matematis bentuk persamaan analisis fungsi Cobb Douglas dapat dirumuskan sebagai berikut (Soekartawi, 1990):

$$
\mathrm{Y}=\mathrm{a}+\mathrm{b}_{1} \mathrm{X}_{1}+\mathrm{b}_{2} \mathrm{X}_{2}+\mathrm{b}_{3} \mathrm{X}_{3}+\mathrm{b}_{4} \mathrm{X}_{4}+\mathrm{b}_{5} \mathrm{X}_{5}+\mathrm{b}_{6} \mathrm{X}_{6}+\mathrm{e}+\mathrm{u}
$$

Untuk menyederhanakan penggunaan, maka fungsi Cobb Douglas ditransformasikan kedalam bentuk logaritma natural (ln), maka didapatkan persamaan sebagai berikut:

$\ln \mathrm{Y}=\ln \mathrm{a}+\mathrm{b}_{1} \ln \mathrm{X}_{1}+\mathrm{b}_{2} \ln \mathrm{X}_{2}+\mathrm{b}_{3} \ln \mathrm{X}_{3}+\mathrm{b}_{4} \ln \mathrm{X}_{4}+\mathrm{b}_{5} \ln \mathrm{X}_{5}+\mathrm{b}_{6} \ln \mathrm{X}_{6}+\mathrm{e}$

Keterangan:

ln = Logaritma natural

$\mathrm{Y} \quad=$ Produksi bawang merah $(\mathrm{Kg} / \mathrm{Ha} / \mathrm{MT})$

$\mathrm{a} \quad=$ Konstanta

$\mathrm{X}_{1}=$ Luas lahan $(\mathrm{Ha} / \mathrm{MT})$

$\mathrm{X}_{2}=$ Bibit $(\mathrm{Kg} / \mathrm{Ha} / \mathrm{MT})$ 
$\mathrm{X}_{3}=$ Pupuk Organik $(\mathrm{Kg} / \mathrm{Ha} / \mathrm{MT})$

$\mathrm{X}_{4} \quad=$ Pupuk Anorganik $(\mathrm{Kg} / \mathrm{Ha} / \mathrm{MT})$

$\mathrm{X}_{5} \quad=$ Pestisida $(\mathrm{Kg} / \mathrm{Ha} / \mathrm{MT})$

$\mathrm{X}_{6}=$ Tenaga Kerja $(\mathrm{HKP} / \mathrm{MT})$

$\mathrm{b}_{1}-\mathrm{b}_{6}=$ Koefisien regresi masing-masing variabel independen $\left(\mathrm{X}_{1}-\mathrm{X}_{6}\right)$

e $\quad=$ Bilangan natural

Untuk keberhasilan dari analisis regresi tersebut maka akan dilakukan uji hipotesis secara statistik menggunakan koefisien determinasi $\left(\mathrm{R}^{2}\right)$, uji simultan (uji-F), dan uji statistik t ( $\mathrm{t}$-test).

a. Koefisien Determinasi $\left(\mathrm{R}^{2}\right)$

Koefisien determinasi (R2) ini digunakan sebagai alat untuk mengukur ketepatan dari model persamaan diatas (Kuncoro, 2013). Tujuan dari koefisien determinasi ini adalah untuk melihat bagaimana model persamaan tersebut dapat menjelaskan kondisi yang sesungguhnya, dapat digunakan rumus sebagai berikut:

$$
\mathrm{R}^{2}=\frac{\text { Jumlah Kuadrat Regresi }}{\text { Jumlah Kuadrat Total }}
$$

b. Uji Simultan (Uji-F)

Uji F merupakan alat uji yang digunakan untuk melihat bagaimana pengaruh variabel bebas secara serempak (bersama-sama) terhadap variabel terikatnya (Sudjana, 2005). Untuk melihat apakah model regresi yang diuji sudah signifikan atau belum juga dapat dilakukan dengan uji $\mathrm{F}$, dengan persamaan sebagai berikut:

$$
\text { F Hit }=\frac{R^{2} / K}{\left(\frac{1-R^{2}}{n-K-1}\right)}
$$

Keterangan:

R2 = Koefisien Determinasi

$\mathrm{K}$ = Jumlah variabel bebas

$\mathrm{n} \quad=$ Jumlah sampel

Berikut hipotesis statistik:

Ho : tidak ada pengaruh signifikan pada input produksi (luas lahan, bibit, pupuk organik, pupuk anorganik, pestisida, dan tenaga kerja) terhadap produksi bawang merah.

Ha : adanya pengaruh signifikan pada input produksi (luas lahan, bibit, pupuk organik, pupuk anorganik, pestisida, dan tenaga kerja) terhadap produksi bawang merah.

Dengan melihat ketentuan sebagai berikut:

- Jika sig (p-value) < $\alpha(0,05)$ menjelaskan bahwa Ho ditolak dan Ha diterima yang berarti adanya pengaruh signifikan pada penggunaan input produksi (luas lahan, bibit, pupuk organik, pupuk anorganik, pestisida, dan tenaga kerja) secara simultan terhadap produksi bawang merah.

- Jika sig ( $p$-value) $>\alpha(0,05)$ menjelaskan bahwa Ho diterima Ha ditolak yang berarti tidak adanya pengaruh signifikan pada penggunaan input produksi (luas lahan, bibit, pupuk organik, pupuk anorganik, pestisida, dan tenaga kerja) secara simultan terhadap produksi bawang merah.

c. Uji Statistik t

Uji statistik t (t-test) merupakan alat uji statistik yang digunakan untuk melihat bagaimana pengaruh variabel bebas terhadap variabel terikatnya secara parsial 
(terpisah) (Kuncoro, 2013). Adapun uji statatisik t-test dapat ditulis dengan persamaan sebagai berikut:

$$
\text { thitung }=\frac{\text { bi }}{\text { Sbi }}
$$

Keterangan:

bi $=$ Koefisien regresi yang dicari

Sbi $=$ Standar error dari koefisien regresi

Berikut hipotesis statistik:

Ho : masing-masing penggunaan input produksi (luas lahan, bibit, pupuk organik, pupuk anorganik, pestisida, dan tenaga kerja) secara parsial tidak berpengaruh signifikan terhadap produksi bawang merah.

$\mathrm{Ha}$ : masing-masing penggunaan input produksi (luas lahan, bibit, pupuk organik, pupuk anorganik, pestisida, dan tenaga kerja) secara parsial berpengaruh signifikan terhadap produksi bawang.merah

Dengan melihat ketentuan sebagai berikut:

- Jika sig (p-value) < $\alpha(0,05)$ menjelaskan bahwa Ho ditolak dan Ha diterima yang berarti adanya pengaruh signifikan pada penggunaan input produksi (luas lahan, bibit, pupuk organik, pupuk anorganik, pestisida, dan tenaga kerja) secara parsial terhadap produksi bawang merah.

- Jika sig (p-value) $>\alpha(0,05)$ menjelaskan bahwa Ho diterima dan Ha ditolak yang berarti tidak adanya pengaruh signifikan pada penggunaan input produksi (luas lahan, bibit, pupuk organik, pupuk anorganik, pestisida, dan tenaga kerja) secara parsial terhadap produksi bawang merah.

\section{Analisis Efisiensi Harga}

Untuk melihat suatu input yang digunakan pada usahatani bawang merah apakah sudah efisien, belum efisien atau tidak efisien maka perlu dilakukan analisis efisiensi. Untuk menghitung efisiensi dari input produksi yang digunakan dapat dilihat dari nilai produk marjinal inputnya (NPMx) sama dengan harga input tersebut (Px) (Hanafie, 2010). Efisiensi penggunaan input produksi dapat dihitung dengan persamaan sebagai berikut:

$$
\mathrm{NPMx}=\mathrm{Px} \text {, atau } \frac{\text { b.Y.Py }}{\mathrm{X}}=\mathrm{Px}
$$

Kondisi efisiensi dari input produksi yang digunakan mengharuskan NPMx sama dengan harga input produksi Px, sehingga dapat ditulis dengan rumus sebagai berikut:

$$
\mathrm{Px}=\frac{\text { b.Y.Py }}{\mathrm{X}} \text { atau } 1=\frac{\mathrm{b} \cdot Y \cdot P y}{\mathrm{X} \cdot \mathrm{Px}}
$$

Keterangan:

NPMx = Nilai produk marginal input

$\mathrm{b} \quad=$ Koefisien regresi

$\mathrm{Y} \quad$ = Rata-rata produksi bawang merah pada masa Covid-19

Py = Harga produksi bawang merah pada masa Covid-19

$\mathrm{X} \quad$ = Rata-rata jumlah penggunaan masing-masing input produksi pada masa Covid-19

Px = Harga masing-masing input produksi pada masa Covid-19

Dengan ketentuan sebagai berikut:

- Jika NPMx/Px = 1 maka penggunaan input produksi (luas lahan, bibit, pupuk organik, pupuk anorganik, pestisida, dan tenaga kerja) sudah efisien, sehingga tidak perlu ditambah atau dikurangi jumlah penggunaan input. 
- Jika NPMx/Px > 1 maka penggunaan input produksi (luas lahan, bibit, pupuk organik, pupuk anorganik, pestisida, dan tenaga kerja) belum efisien, sehingga perlu ditambah jumlah penggunaan input.

- Jika NPMx/Px $<1$ maka penggunaan input produksi (luas lahan, bibit, pupuk organik, pupuk anorganik, pestisida, dan tenaga kerja) tidak efisien, sehingga perlu dikurangi jumlah penggunaan input.

\section{HASIL DAN PEMBAHASAN}

\section{Penggunaan Input Produksi Bawang Merah}

Total produksi bawang merah saat ini adalah sebesar $19.750 \mathrm{~kg}$ atau 19,57 ton. Rata-rata produksi bawang merah per petani adalah sebanyak $1.087,2 \mathrm{~kg}$ dan rata-rata produksi bawang merah per hektar adalah sebanyak $3.741,87 \mathrm{~kg}$ dengan harga jual bawang merah rata-rata sebesar Rp33.500,-/kg. Tingginya harga jual bawang merah disebabkan karena keterlambatan bibit yang dibagikan oleh pemerintah kepada petani sehingga penanaman bawang merah dilakukan pada musim hujan yang membuat produksinya tidak optimal dan hal ini mempengaruhi persediaan bawang merah yang langka. Petani di Peukan Bada selama masa pandemi hanya melakukan usahatani bawang merah satu kali dalam setahun.

Rata-rata luas lahan per petani adalah sebesar 0,29 ha dan rata-rata luas lahan per hektar adalah 1. Pada tanaman bawang merah petani menggunakan jarak tanam $15 \times 20 \mathrm{~cm}$ serta jarak antar bedengan $30 \mathrm{~cm}$. Bawang merah dapat dipanen setelah 60 hingga 75 hari. Lahan usahatani bawang merah di Peukan Bada secara keseluruhan merupakan lahan milik pribadi. Namun untuk melihat efisiensi harga maka diperlukan biaya sewa lahan pada Kecamatan Peukan Bada dengan rata-rata biaya sewa sebesar Rp2.700.000,-/Ha/MT.

Total bibit yang digunakan dalam satu kali musim tanam pada masa pandemi berjumlah $4110 \mathrm{~kg}$. Rata-rata penggunaan bibit per petani adalah sebesar 228,33 kg dan rata-rata penggunaan bibit per hektarnya adalah $785,85 \mathrm{~kg}$, dengan harga per $\mathrm{kg}$ bibit tersebut mencapai Rp. 54.000,- per kg. Harga bibit diketahui berdasarkan perkiraan yang diberikan oleh Balai Penyuluh Pertanian Peukan Bada.

Total keseluruhan penggunaan pupuk organik dalam satu kali musim tanam adalah 7580 $\mathrm{kg}$. Rata-rata penggunaan pupuk organik per petani adalah sebanyak $421,11 \mathrm{~kg}$ dan rata-rata penggunaan pupuk organik per hektar adalah sebanyak $1.449,33 \mathrm{~kg}$ kemudian biaya penggunaan pupuk organik per petani adalah sebesar Rp. 294.777,98,- dan biaya penggunaan pupuk organik per hektar adalah sebesar Rp1.014.531,55,-. Pupuk organik dibeli petani dengan harga Rp. 700,-/kg.

Total keseluruhan penggunaan pupuk anorganik dalam satu kali musim tanam adalah 748 $\mathrm{kg}$. Rata-rata penggunaan pupuk anorganik per petani adalah sebanyak 41,56 kg dan rata-rata penggunaan pupuk anorganik per hektar adalah sebanyak 143,02 kg kemudian biaya penggunaan pupuk anorganik per petani adalah sebesar Rp. 95.577,78,- dan biaya penggunaan pupuk anorganik per hektar adalah sebesar Rp. 328.948,37,-. Pupuk anorganik dibeli petani dengan harga Rp. 2.300,-/kg.

Total keseluruhan penggunaan pestisida pada satu kali musim tanam adalah 5,9 kg. Ratarata penggunaan pestisida per petani adalah sebanyak $0,33 \mathrm{~kg}$ dan rata-rata penggunaan pestisida per hektar adalah $1,13 \mathrm{~kg}$ kemudian biaya penggunaan pestisida per petani adalah sebesar Rp. 42.611,11,- dan biaya penggunaan pestisida per hektar adalah sebesar Rp. 146.653,92,-. Pestisida dibeli petani dengan harga Rp. 130.000,- /kg.

Rata-rata penggunaan tenaga kerja usahatani bawang merah di Peukan Bada adalah sebesar 16,93 HKP per petani atau 58,3 HKP per Ha. Penggunaan tenaga kerja terbanyak ada 
pada kegiatan persiapan lahan yaitu sebesar 7,99 HKP per petani atau 27,51 HKP per Ha. Total keseluruhan biaya yang dikeluarkan untuk kegiatan usahatani bawang merah adalah Rp1.462.571,43,- per petani dan Rp5.033.706,64,- per hektar. Biaya penggunaan tenaga kerja terbanyak ada pada kegiatan persiapan lahan yang berjumlah sebesar Rp. 799.206,35,- per petani dan Rp. 2.750.614,59,- per hektar. Pada kegiatan persiapan lahan dan penanam petani memberi upah sebesar Rp100.000,-, sedangkan pada kegiatan pemupukan, pemeliharaan serta panen dan pasca panen petani memberikan upah sebesar Rp70.000,-.

\section{Pengaruh Input Produksi terhadap Produksi Bawang Merah}

Rendah tingginya hasil produksi sangat dipengaruhi oleh input-input produksi yang digunakan. Input produksi yang digunakan pada penelitian ini adalah luas lahan (X1), bibit (X2), pupuk organik (X3), pupuk anorganik (X4), pestisida (X5) dan tenaga kerja (X6). Untuk mengetahui hubungan antara input produksi tersebut dengan jumlah produksi maka dilakukan analisis fungsi Cobb Douglas.

Tabel 1. Hasil analisis regresi penggunaan input produksi terhadap produksi bawang merah

\begin{tabular}{|c|c|c|c|c|c|}
\hline Variabel Bebas & Koefisien Regresi & Thitung & Sig & Fhitung & Sig \\
\hline Konstanta & $-5,423$ & $-0,755$ & 0,466 & & \\
\hline $\operatorname{LnX}_{1}$ (Luas Lahan) & $-1,03$ & $-0,989$ & 0,344 & & \\
\hline $\operatorname{LnX}_{2}$ (Bibit) & 0,951 & 3,312 & 0,007 & & \\
\hline LnX $_{3}$ (Pupuk Organik) & $-0,239$ & $-0,402$ & 0,696 & 26,535 & 0,000 \\
\hline $\operatorname{LnX}_{4}$ (Pupuk Anoganik) & 1,383 & 1,515 & 0,158 & & \\
\hline $\operatorname{LnX}_{5}$ (Pestisida) & $-0,215$ & $-0,588$ & 0,568 & & \\
\hline LnX $_{6}($ Tenaga Kerja) & 0,622 & 0,829 & 0,425 & & \\
\hline
\end{tabular}

Sumber : data primer diolah, 2021 berikut:

Berdasarkan tabel di atas dapat dituliskan sebuah model persamaan regresi sebagai $\hat{Y}=-5,423-1,03 \operatorname{LnX}_{1}+0,951 \operatorname{LnX}_{2}-0,239 \operatorname{LnX} 3+1,383 \operatorname{LnX}_{4}-0,215 \operatorname{LnX}_{5}+0,622 \operatorname{LnX}_{6}$ Dari persamaan diatas dapat di dijelaskan bahwa nilai konstanta adalah $-5,423$ yang merupakan bernilai negatif dengan makna jika variabel luas lahan, bibit, pupuk organik, pupuk anorganik, pestisida dan tenaga kerja tidak ada atau sama dengan nol maka produksi bawang merah akan berkurang. Pada variabel $\mathrm{X}_{1}$ (luas lahan) diketahui nilai koefisien regresi adalah -1,03 dengan makna bahwa pengaruh luas lahan terhadap produksi bernilai negatif. Jika areal luas lahan dikurangi sebesar $1 \%$ maka produksi bawang merah akan berkurang sebesar 1,03\%. Pada variabel $\mathrm{X}_{2}$ (bibit) diketahui nilai koefisien regresi adalah 0,951 dengan makna bahwa pengaruh bibit terhadap produksi bernilai positif. Jika bibit yang digunakan meningkat sebesar $1 \%$ maka produksi bawang merah akan meningkat sebesar $0,951 \%$. Pada variabel $\mathrm{X}_{3}$ (pupuk organik) diketahui nilai koefisien regresi adalah -0,239 dengan makna bahwa pengaruh pupuk organik terhadap produksi bernilai negatif. Jika pupuk organik yang digunakan dikurangi sebesar $1 \%$ maka produksi bawang merah akan menurun sebesar 0,239\%. Pada variabel $\mathrm{X}_{4}$ (pupuk anorganik) diketahui nilai koefisien regresi adalah 1,383 dengan makna bahwa pengaruh pupuk organik terhadap produksi bernilai positif. Jika pupuk anorganik yang digunakan meningkat sebesar $1 \%$ maka produksi bawang merah akan meningkat sebesar $1,383 \%$. Pada variabel $\mathrm{X}_{5}$ (pestisida) diketahui nilai koefisien regresi adalah -0,215 dengan makna bahwa pengaruh pestisida terhadap produksi bernilai negatif. Jika pestisida yang digunakan dikurangi sebesar $1 \%$ maka produksi bawang merah akan berkurang sebesar $0,215 \%$. Pada variabel $\mathrm{X}_{6}$ (tenaga kerja) diketahui nilai koefisien regresi adalah 0,622 dengan makna bahwa pengaruh tenaga 
kerja terhadap produksi bernilai positif. Jika tenaga kerja yang digunakan meningkat sebesar $1 \%$ maka produksi bawang merah akan meningkat sebesar $0,622 \%$.

Pada tabel 1 juga dapat diketahui nilai koefisien determinasi $\left(\mathrm{R}^{2}\right)$ yang didapatkan yakni sebesar 0,935 yang menjelaskan bahwa sebanyak 93,5\% produksi usahatani bawang merah dipengaruhi oleh variabel luas lahan, bibit, pupuk organik, pupuk anorganik, pestisida dan tenaga kerja sedangkan 6,5\% sisanya dijelaskan oleh faktor lain diluar penelitian ini. Data dari tabel 1 juga menerangkan bahwa dengan uji $\mathrm{F}$ ini diketahui adanya pengaruh simultan yang signifikan dari semua variabel bebas yang digunakan meliputi luas lahan, bibit, pupuk organik, pupuk anorganik, pestisida dan tenaga kerja terhadap produksi. Hal ini dapat dilihat dari nilai signifikan yang diperoleh yaitu $0,000<0,05$ yang berarti bahwa penggunaan input produksi yang meliputi luas lahan, bibit, pupuk organik, pupuk anorganik, pestisida dan tenaga kerja secara serempak (bersama-sama) berpengaruh secara signifikan terhadap produksi bawang merah di Kecamatan Peukan Bada.

Kemudian tabel 1 juga menunjukkan secara parsial bagaimana pengaruh masing-masing input produksi terhadap produksi bawang merah. Pada variabel luas lahan, maka diperoleh nilai signifikansi 0,344>0,05 yang berarti bahwa tidak adanya pengaruh signifikan pada penggunaan luas lahan terhadap produksi bawang merah. Tidak adanya pengaruh yang signifikan pada luas lahan produksi bawang merah dikarenakan luas lahan untuk melakukan usahatani bawang merah di Peukan Bada relatif kecil.

Pada variabel bibit diperoleh nilai signifikansi $0,007<0,05$ yang berarti bahwa adanya pengaruh signifikan pada penggunaan input produksi bibit terhadap produksi bawang merah. Hal ini menjelaskan bahwa setiap bertambahnya penggunaan bibit akan bertambah pula hasil produksi usahataninya, sebaliknya apabila penggunaan bibit berkurang maka berkurang pula hasil produksi usahataninya. Adanya pengaruh yang signifikan pada penggunaan bibit dikarenakan bibit yang digunakan oleh petani merupakan bibit varietas bima brebes yang memiliki daya tahan yang tinggi terhadap penyakit.

Kemudian pada variabel pupuk organik diperoleh nilai signifikansi 0,696>0,05 yang berarti bahwa tidak adanya pengaruh signifikan pada penggunaan pupuk organik terhadap produksi bawang merah. Tidak adanya pengaruh yang signifikan pada penggunaan pupuk organik dikarenakan penyebarannya yang tidak merata. Penggunaan yang tidak sesuai disebabkan oleh petani yang memberikan pupuk dengan tidak memperhitungkan areal lahan yang ditanami.

Pada variabel pupuk anorganik diperoleh nilai signifikansi 0,158>0,05 yang berarti bahwa tidak adanya pengaruh signifikan pada penggunaan pupuk anorganik terhadap produksi bawang merah. Tidak adanya pengaruh yang signifikan pada penggunaan pupuk anorganik dikarenakan penggunaannya yang sudah berjalan terus-menurus dari tahun ke tahun sehingga terjadi perubahan pada struktur tanah dan kandungan unsur hara yang terdapat didalamnya menurun.

Pada variabel pestisida diperoleh nilai signifikansi $0,568>0,05$ yang berarti bahwa tidak adanya pengaruh signifikan pada penggunaan input pestisida terhadap produksi bawang merah. Tidak adanya pengaruh yang signifikan pada penggunaan pestisida dikarenakan penggunaannya yang tidak sesuai dengan takaran yang tertera pada panduan. Penggunaan pestisida dengan dosis yang tidak tepat akan membuat pestisida tidak dapat berkerja dengan optimal.

Pada variabel tenaga kerja diperoleh nilai signifikansi $0,425>0,05$ yang berarti bahwa tidak adanya pengaruh signifikan pada penggunaan input tenaga kerja terhadap produksi bawang merah. Tidak adanya pengaruh yang signifikan pada penggunaan tenaga kerja dikarenakan kuantitas tenaga kerja yang dikurangi sehingga penggunaannya tidak optimal. 


\section{Tingkat Efisiensi Penggunaan Input Produksi Bawang Merah}

Dalam mengamati bagaimana tingkat efisiensinya maka perlu diperhatikan harga dari setiap input produksi yang digunakan yaitu luas lahan, bibit, pupuk organik, pupuk anorganik, pestisida dan tenaga kerja. Efisiensi mengacu pada sebuah usaha dalam meminimalisir penggunaan input untuk memperoleh hasil output yang maksimal. Efisiensi harga dapat terlaksana jika petani mampu mendapatkan keuntungan yang maksimum, dengan cara menyamakan nilai produk marjinal dari setiap input sama dengan biaya inputnya.

Tabel 2. Tingkat efisiensi penggunaan input produksi pada usahatani bawang merah

\begin{tabular}{llllll}
\hline No & Input Produksi & NPMx & Px & NPMx/Px & Keterangan \\
\hline 1 & Luas Lahan & $-129.361 .624,66$ & 2.700 .000 & $-47,91$ & Tidak efisien \\
2 & Bibit & $151.699,37$ & 54.000 & 2,81 & Belum efisien \\
3 & Pupuk Organik & $-20.671,34$ & 700 & $-29,53$ & Tidak efisien \\
4 & Pupuk Anorganik & $1.610 .779,90$ & 2.300 & 700,34 & Belum efisien \\
5 & Pestisida & $-23.729 .618,41$ & 130.000 & $-182,54$ & Tidak efisien \\
6 & Tenaga Kerja & $1.337 .334,24$ & 100.000 & 13,37 & Belum efisien \\
\hline
\end{tabular}

Sumber : data primer diolah, 2021

Pada tabel 2 variabel luas lahan menunjukkan bahwa nilai NPMx/Px yaitu $-47,91<1$ hal ini menunjukkan bahwa penggunaan luas lahan pada usahatani bawang merah di Peukan Bada tidak efisien bila diamati dari segi harga. Oleh karena itu perlu dilakukannya pengurangan pemakaian luas lahan untuk mendapatkan produksi bawang merah yang maksimal. Namun karena lahan tidak memungkinkan untuk dikurangi, maka dapat dilakukan dengan cara menambah input produksi lain agar mencapai efisiensi, dengan tercapainya efisiensi akan memaksimalkan pendapatan petani bawang merah di Peukan Bada.

Pada variabel bibit menunjukkan bahwa nilai NPMx/Px yaitu 2,81>1 hal ini menunjukkan bahwa penggunaan bibit pada usahatani bawang merah di Peukan Bada belum efisien bila diamati dari segi harga. Oleh karena itu dalam upaya untuk meningkatkan produksi perlu dilakukannya penambahan bibit bawang merah agar mencapai efisiensi, dengan tercapainya efisiensi akan memaksimalkan pendapatan petani bawang merah di Peukan Bada.

Kemudian pada variabel pupuk organik menunjukkan bahwa nilai NPMx/Px yaitu -29,53 $<1$ hal ini menunjukkan bahwa penggunaan pupuk organik pada usahatani bawang merah di Peukan Bada tidak efisien bila diamati dari segi harga. Oleh karena itu pemakaian pupuk organik perlu dikurangi untuk meningkatkan hasil produksi dan mencapai efisiensi, dengan tercapainya efisiensi akan memaksimalkan pendapatan petani bawang merah di Peukan Bada.

Pada variabel pupuk anorganik menunjukkan bahwa nilai NPMx/Px yaitu 700,34 > 1 hal ini menunjukkan bahwa penggunaan pupuk anorganik pada usahatani bawang merah di Peukan Bada belum efisien bila diamati dari segi harga. Oleh karena itu penggunaan pupuk anorganik perlu dilakukan penambahan agar tercapainya efisiensi dan meningkatnya produksi, dengan tercapainya efisiensi akan memaksimalkan pendapatan petani bawang merah di Peukan Bada.

Kemudian pada variabel pestisida menunjukkan bahwa nilai NPMx/Px yaitu $182,54<1$ hal ini menunjukkan bahwa penggunaan pestisida pada usahatani bawang merah di Peukan Bada tidak efisien bila diamati dari segi harga. Oleh karena itu perlu dilakukan pengurangan pemakaian pestisida agar tercapainya efisiensi dan meningkatnya produksi, 
dengan tercapainya efisiensi akan memaksimalkan pendapatan petani bawang merah di Peukan Bada.

Kemudian pada variabel tenaga kerja menunjukkan bahwa nilai NPMx/Px yaitu 13,37 > 1 hal ini menunjukkan bahwa penggunaan pestisida pada usahatani bawang merah di Peukan Bada belum efisien bila diamati dari segi harga. Oleh karena itu perlu dilakukan penambahan tenaga kerja agar proses kegiatan produksi lebih cepat untuk dilakukan sehingga dapat meningkatkan produksi dan tercapainya efisiensi, dengan tercapainya efisiensi akan memaksimalkan pendapatan petani bawang merah di Peukan Bada.

Dari masing-masing penggunaan input maka didapatkan total nilai efisiensi harga adalah sebesar 76,09 yang dihitung dari penambahan setiap hasil NPMx/Px pada masing-masing input produksi dibagi dengan kesuluruhan input produksi. Nilai tersebut menjelaskan bahwa usahatani bawang merah di Kecamatan Peukan Bada pada masa pandemi Covid-19 ini belum efisien secara harga.

\section{Simpulan}

\section{SIMPULAN DAN SARAN}

Beralaskan uraian yang didapatkan pada hasil dan pembahasan, maka dapat diambil kesimpulan seperti dibawah ini:

1. Input produksi berupa luas lahan, bibit, pupuk organik, pupuk anorganik, pestisida dan tenaga kerja berpengaruh signifikan secara simultan terhadap produksi usahatani bawang merah. Sedangkan itu secara parsial hanya bibit yang berpengaruh signifikan terhadap produksi bawang merah sementara luas lahan, pupuk organik, pupuk anorganik, pestisida dan tenaga kerja tidak berpengaruh signifikan terhadap produksi bawang merah pada masa pandemi Covid-19.

2. Penggunaan input produksi yang belum efisien pada usahatani bawang merah di Kecamatan Peukan Bada pada masa pandemi Covid-19 adalah penggunaan input bibit, pupuk anorganik dan tenaga kerja, sehingga dibutuhkan penambahan pada input produksi diatas agar tercapainya produksi yang maksimal. Sedangkan penggunaan input produksi yang tidak efisien pada usahatani bawang merah di Kecamatan Peukan Bada pada masa pandemi Covid-19 adalah penggunaan input luas lahan, pupuk organik, dan pestisida, hal ini membutuhkan pengurangan pada setiap input produksi agar tercapainya produksi yang maksimal.

\section{Saran}

Beralaskan uraian pada hasil dan pemahasan maka dapat diberikan saran sebagai berikut:

1. Pada masa pandemi Covid-19 diharapkan adanya peran dari Balai Penyuluh Pertanian ataupun dari Dinas Perkebunan untuk membantu petani dalam mengalokasikan input produksi secara tepat sehingga dapat membantu petani dalam memperoleh hasil produksi yang maksimal.

2. Diharapkan kepada petani agar dapat mengalokasikan penggunaan input lebih tepat, seperti menambah penggunaan bibit, pupuk anorganik dan tenaga kerja serta mengurangi penggunaan luas lahan, pupuk organik dan pestisida agar penggunaan input tersebut efisien, dengan tercapainya efisiensi dapat membantu petani mengurangi biaya yang berlebihan sehingga lebih menghemat pengeluaran terlebih pada masa pandemi ini.

3. Diharapkan juga kepada petani untuk dapat mengembangkan bibit bawang merah dengan mandiri agar tidak bergantung pada bibit bantuan seperti pada masa pandemi ini, sehingga pada saat musim tanam tiba petani dapat langsung melakukan penanaman. 


\section{DAFTAR PUSTAKA}

Abdi, F. I., Hasyim, H., \& Ayu, S. F. (2014). Faktor-Faktor Yang Berpengaruh Terhadap Penggunaan Tenaga Kerja Luar Keluarga Pada Usaha Tani Padi Sawah. Journal Of Agriculture And Agribusiness Socioeconomics, 2(7), 15085.

Aldila, H. F., Fariyanti, A., \& Tinaprilla, N. (2015). Analisis Profitabilitas Usahatani Bawang Merah Berdasarkan Musim Di Tiga Kabupaten Sentra Produksi Di Indonesia. Sepa: Jurnal Sosial Ekonomi Pertanian Dan Agribisnis, 11(2), 249-260.

Andriyani, W. (2014). Analisis Produksi Dan Pendapatan Usahatani Bawang Merah Lokal Tinombo Di Desa Lombok Kecamatan Tinombo Kabupaten Parigi Moutong. Agrotekbis, 2(5).

Anggraini, N., Harianto, H., \& Anggraeni, L. (2016). Efisiensi Teknis, Alokatif Dan Ekonomi Pada Usahatani Ubikayu Di Kabupaten Lampung Tengah Provinsi Lampung. Jurnal Agribisnis Indonesia, 4(1), 43-56.

Hanafie, R. (2010). Pengantar Ekonomi Pertanian. Penerbit Andi.

Hayati, M., Hayati, E., \& Denni, D. (2011). Pengaruh Pupuk Organik Dan Anorganik Terhadap Pertumbuhan Beberapa Varietas Jagung Manis Di Lahan Tsunami. Jurnal Floratek, 6(1), 74-83.

Hervani, D., Lili, S., \& Etti, S. (2009). Teknologi Budidaya Bawang Merah Pada Beberapa Media Dalam Pot Di Kota Padang. Jurnal Warta Pengabdian Andalas. 15: 1, 22.

Kuncoro, M. (2013). Metode Riset Untuk Bisnis \& Ekonomi, Edisi Keempat. Jakarta: Erlangga.

Laksmayani, M. K., Laapo, A., \& Sulaeman, H. (2013). Analisis Efisiensi Penggunaan Input Produksi Usahatani Semangka Di Desa Maranatha Kecamatan Sigi Biromaru Kabupaten Sigi. Agrotekbis, 1(2).

Mambu, S. M., \& Pelealu, J. (2020). Pkm Kelompok Tani Cabai Di Desa Sea Kecamatan Pineleng Kabupaten Minahasa Provinsi Sulawesi Utara Tentang Pemanfaatan Plant Growth Promoting Rhizobacteria Dan Mikoriza Untuk Meningkatkan Produksi Cabai Pada Lahan Sub-Optimal. Vivabio: Jurnal Pengabdian Multidisiplin, 2(3), 20-24.

Maulana, R. I., Gayatri, S., \& Dalmiyatun, T. (2019). Pengaruh Curahan Waktu Kerja Wanita Tani Tembakau Terhadap Penerimaan Keluarga Di Kecamatan Jumo Kabupaten Temanggung. Jsep (Journal Of Social And Agricultural Economics), 12(2), 92-105.

Mujianto, M. (2016). Dampak Penerapan Harga Dasar Terhadap Input Produksi Dan Pendapatan Usaha Tani (Kasus Desa Clumprit Kabupaten Malang). Nabatia, 1(1), 6370.

Nurjati, E., Fahmi, I., \& Jahroh, S. (2018). Analisis Efisiensi Produksi Bawang Merah Di Kabupaten Pati Dengan Fungsi Produksi Frontier Stokastik Cobb-Douglas. Jurnal Agro Ekonomi, 36(1), 55-69.

Nurmala, N., \& Antara, M. (2015). Analisis Efisiensi Penggunaan Input Produksi Usahatani Cengkeh Di Kecamatan Dako Pemean Kabupaten Tolitoli. Agroland: Jurnal Ilmu-Ilmu Pertanian, 22(3), 226-234.

Rahayu, H. S. P., Muchtar, M., \& Saidah, S. (2019). The Feasibility And Farmer Perception Of True Shallot Seed Technology In Sigi District, Central Sulawesi, Indonesia. Asian Journal Of Agriculture, 3(01), 16-21.

Rahmah, A., Sipayung, R., \& Simanungkalit, T. (2013). Pertumbuhan Dan Produksi Bawang Merah (Allium Ascalonicum L.) Dengan Pemberian Pupuk Kandang Ayam Dan Em4 (Effective Microorganisms4. Jurnal Agroekoteknologi Universitas Sumatera Utara, 1(4), 95606.

Rijal, M., Jakfar, F., \& Widyawati, W. (2016). Analisis Faktor-Faktor Yang Mempengaruhi 
Produksi Usahatani Bawang Merah Di Desa Lam Manyang Kecamatan Peukan Bada. Jurnal Ilmiah Mahasiswa Pertanian, 1(1), 488-497.

Rizal, R. (2014). Analisis Efisiensi Penggunaan Input Produksi Usahatani Padi Sawah Di Desa Toribulu Kecamatan Toribulu Kabupaten Parigi Moutong. Agroland: Jurnal Ilmu-Ilmu Pertanian, 21(1).

Rosnani, R. (2020). Analisa Kandungan Kadmium (Cd) Pada Bawang Merah (Allium Cepa) Di Kelurahan Mataran Kecamatan Anggeraja Kabupaten Enrekang. Sulolipu: Media Komunikasi Sivitas Akademika Dan Masyarakat, 19(2), 239-245.

Santoso, W., Usman, A., \& Yusuf, M. (2017). Analisis Efisiensi Penggunaan Input Produksi Pada Usahatani Bawang Merah Di Kecamatan Plampang, Kabupaten Sumbawa, Nusa Tenggara Barat. Agroteksos: Agronomi Teknologi Dan Sosial Ekonomi Pertanian, 25(1), 123-130.

Soekartawi. (1990). Teori Ekonomi Produksi Dengan Pokok Bahasan Analisis Fungsi CobbDouglas. Rajawali.

Sudjana. (2005). Metode Statistika. Tarsito.

Sugiyono. (2009). Metode Penelitian Kuantitatif, Kualitatif Dan R\&D. Alfabeta.

Widanta, A. A. B. P. (2017). Pengaruh Luas Lahan, Teknologi Dan Pelatihan Terhadap Pendapatan Petani Padi Dengan Produktivitas Sebagai Variabel Intervening Di Kecamatan Mengwi. E-Jurnal Ekonomi Pembangunan Universitas Udayana, 6(8), $1601-1627$.

Widiawati, I. D. G. R. S., \& Djelantik, A. A. A. W. S. (N.D.). Analisis Efisiensi Penggunaan Input Produksi Pada Usahatani Bawang Merah Di Desa Songan B, Kecamatan Kintamani, Kabupaten Bangli. Jurnal Agribisnis Dan Agrowisata Issn, 3685, 3809.

Yuantari, M. G. C. (2013). Tingkat Pengetahuan Petani Dalam Menggunakan Pestisida (Studi Kasus Di Desa Curut Kecamatan Penawangan Kabupaten Grobogan. 